\title{
Novel Synthesis of Nay Zeolite from Rice Husk Silica: Modification with Zno and Zns for Antibacterial Application
}

Tarek M Salama ${ }^{1 *}$, Ibraheem O Ali ${ }^{1,2}$, Hosni A Gumaa1, Mohamed A Lateef ${ }^{3}$ and Mostafa F Bakr ${ }^{1}$

${ }^{1}$ Chemistry Department, Faculty of Science, Al-Azhar University, Nasr City 11884, Cairo, Egypt

${ }^{2}$ Chemistry Department, College of Science and Arts, Al Jouf University, Algrayuat, KSA

${ }^{3} \mathrm{New}$ Urban Communities Authority (NUCA) 6th October, Giza, Egypt

\begin{abstract}
Zeolite $\mathrm{Y}$ in the sodium form (NaY) was synthesized using amorphous silica ash derived from waste rice husks under hydrothermal conditions. Structural characterization of $\mathrm{NaY}$ before and after modification with $\mathrm{ZnO}$ and $\mathrm{ZnS}$ has been done using powder X-ray diffraction (XRD), X-ray photoelectron spectroscopy (XPS), $\mathrm{N}_{2}$ adsorption-desorption at $-196{ }^{\circ} \mathrm{C}$, scanning electron microscopy (SEM) and Fourier transform infrared (FTIR) spectroscopy. The effects of the $\mathrm{Na}_{2} \mathrm{O} / \mathrm{SiO}_{2}$ and $\mathrm{Si} / \mathrm{Al}$ ratios, aging temperature and crystallization time on the optimized synthesis of $\mathrm{NaY}$ were thoroughly investigated. Thus the regulated $\mathrm{Na}^{+}$impurity concentration in the starting hydrogel was found to act as a template-assisted synthesis of zeolite $\mathrm{NaY}$ by the potential incorporation of Al atoms into the zeolite framework. Results of surface analyses indicate that the interactions of $\mathrm{ZnO}$ and $\mathrm{ZnS}$ with $\mathrm{NaY}$ zeolite are distinguishable and thus the higher interaction is observed for the latter. While $\mathrm{Zn}^{\prime \prime}$ has experienced electrostatic bonding interaction with the framework oxygen atoms, creation of mesopores in NaY due to local destruction of the zeolite lattice around the growing $\mathrm{ZnS}$ particles was evidenced. Wonderfully, $\mathrm{ZnS} / \mathrm{NaY}$ exhibited a high performance in prohibiting the growth of Escherichia coli (E. coli) and negligible from P. Aeruginosa, and these important features make it a potential candidate as an antimicrobial agent for controlling implant-related infections.
\end{abstract}

Keywords: Zeolite Y; Zno; Zns; XPS; Antibacterial activity

\section{Introduction}

Zeolite Y (FAU-type) is one of the most important "big five" zeolites in terms of the most of industrial catalytic processes use [1]. Basically, the major applications of synthetic zeolite $\mathrm{Y}$ are in the fields of fluid catalytic cracking (FCC) of vacuum gas, oil and in the adsorption of volatile organics from wet off-gas streams [2]. Zeolite $\mathrm{Y}$ is characterized by a high surface area, uniform pore size distribution, inner pore diameter of $12 \AA$ and a relatively large pore opening of $7.4 \AA$ [3]. Due to the uniformity and large pore dimensions, zeolite $\mathrm{Y}$ is chosen as a host for many transition metal complexes which form the active dopants upon deposition [4]. Zeolite Y based-encapsulated metal complexes could be considered as novel catalysts, owing to which possess the so-called bi-functional catalysts. They have the advantages of both homogeneous and heterogeneous catalysts, such as high activity and the ease of separation for re-use. Besides, the encapsulated complexes are considered to be thermally stable under the conditions of zeolite synthesis, i.e. high $\mathrm{pH}$ and elevated temperature. This suggests that they may be suitable for industrial applications.

Rice husk (RH) is a solid waste product from undesirable agricultural mass residue. It increases the economic and environmental burden. So far, the only realized utilization of rice husk is by low technology applications such as in concrete, power plant and cattle feed. Nevertheless, more than 100 million tons/year of $\mathrm{RH}$ are produced globally, of which only a little part is effectively used [5]. Thus, implementation in terms of the use of raw materials will help minimize $\mathrm{RH}$ wastage.

The ash from the unwashed RH contains about 96\% (w/w) amorphous silica. RH can thus be used as an alternative cheap source of amorphous silica for the production of silicon based materials with industrial and technological interests [6,7]. In Egypt an enormous quantity of industrial grade waste of $\mathrm{RH}$ has been produced. Yet, industrial waste $\mathrm{RH}$ can be used as a potentially attractive source for the large scale production of zeolite to protect the environment and decrease the amount of RH waste products. There have been some reports on the utilization of silica from $\mathrm{RH}$ for the synthesis of various types of zeolite [8-14], and mesoporous silica such as MCM- 41 [15]. Efforts have also been made to use RH as a source of silica for the synthesis of $\mathrm{NaY}$ zeolite with the autoclave process. This low-cost process may lead to production of zeolite $\mathrm{NaY}$ to be economically able to compete with established commercial zeolite [16]. Zeolites could selectively adsorb biopolymers like protein, DNA, and RNA, and therefore could be used as chromatographic carriers for these molecules [17-20]. For these reasons, zeolites would be able to selectively adsorb microbial cells and could be used as cell separation carriers in their native state without surface modifications. Zeolites could adsorb each of the bacterial cell species with high selectivity even from a mixed suspension and could therefore be used as effective carrier materials to provide an easy, rapid and accurate method for cell separation [21]. Zinc oxide supported on zeolite with novel physicochemical properties has recently synthesized [22]. There are some reports regarding the industrial uses of $\mathrm{ZnO} /$ zeolite [23-25]. This system can also provide significant impact on the design of a controlled-release product for the pharmacological application in alleviating post-weaning diarrhea of piglets.

The aim of this research was to use the $\mathrm{RH}$ as an amorphous silica source in the synthesis of $\mathrm{NaY}$ zeolite under the optimized experimental conditions. The effects of gel aging and crystallization conditions for the synthesis of $\mathrm{NaY}$ under fully optimized condition were thoroughly investigated. Following the optimization of $\mathrm{NaY}$ synthesis, $\mathrm{ZnO}$ and

*Corresponding author: Tarek M Salama, Chemistry Department, Faculty of Science, Al-Azhar University, Nasr City 11884, Cairo, Egypt, Tel: +20 2 22629357/8 extn. 187/188; Fax:+20222629356; E-mail: tm_salama@yahoo.com

Received February 09, 2016; Accepted February 11, 2016; Published February 18, 2016

Citation: Salama TM, Ali IO, Gumaa HA, Lateef MA, Bakr MF (2016) Novel Synthesis of Nay Zeolite from Rice Husk Silica: Modification with Zno and Zns for Antibacterial Application. Chem Sci J 7: 118. doi:10.4172/2150-3494.1000118

Copyright: (C) 2016 Salama TM, et al. This is an open-access article distributed under the terms of the Creative Commons Attribution License, which permits unrestricted use, distribution, and reproduction in any medium, provided the original author and source are credited. 
ZnS nanoparticles were introduced for comparative purposes. Due to their pronounced electrostatic interactions with $\mathrm{NaY}$ zeolite, they enable a homogenous dispersion of zinc oxide and zinc sulphide into/onto the zeolite by a simple co-precipitation process. The $\mathrm{ZnO}$ and $\mathrm{ZnS}$-modified $\mathrm{NaY}$ zeolite were finally tested for antimicrobial properties.

\section{Experimental Methods}

\section{Materials}

Sodium aluminate powder ( 55-56\%, Fluka), sodium hydroxide pellets (A.R 98\%), zinc(II) acetate hexahydrate (Merck), sodium sulfide pellets $(\mathrm{BDH})$ were used in the present experiments.

Dry rice husk $(\mathrm{RH})$, being used to produce amorphous silica, was sieved to eliminate residual rice and clay particles, washed thoroughly with distilled water, filtered and air-dried at room temperature. The neat, cleaned $\mathrm{RH}$ was dipped into an appropriate volume of hydrochloric acid (3\%) and subjected to stirring for $1 \mathrm{~h}$. This aims at removing metallic impurities. It was then filtered off, and washed again with distilled water until finally chloride ions are removed by checking of chloride ions using $\mathrm{AgNO}_{3}$ solution. The acid treated $\mathrm{RH}$ was airdried at $100{ }^{\circ} \mathrm{C}$ and then calcined at $750{ }^{\circ} \mathrm{C}$ for $6 \mathrm{~h}$ to get white silica rich ash (RH). The yield of silica in RH was determined by XRF analysis and found to be $81.6 \%(\mathrm{w} / \mathrm{w})$.

\section{Synthesis of zeolite $\mathrm{NaY}$ using RH as the silica source}

Effect of $\mathrm{Na}_{2} \mathrm{O} / \mathrm{SiO}_{2}$ molar ratio: Silica extracted from $\mathrm{RH}$ was used as an amorphous silica source for the synthesis of $\mathrm{NaY}$ zeolite by the hydrothermal treatment. The molar composition of the reaction gel was: $\mathrm{xNa}_{2} \mathrm{O}: 1.76 \mathrm{Al}_{2} \mathrm{O}_{3}: \mathrm{ySiO}_{2}: 125 \mathrm{H}_{2} \mathrm{O}$, where $0.69 \leq \mathrm{x} / \mathrm{y}$ ratio $\leq 1.01$. A calculated amount of $\mathrm{NaOH}$ was dissolved in $75 \mathrm{ml}$ distillate water, and then added to a calculated amount of silica in $75 \mathrm{ml}$ distilled water. The mixture was allowed to stir at room temperature followed by heating to $80^{\circ} \mathrm{C}$ until a clear solution of sodium silicate was obtained (solution A). Sodium aluminate $(6.44 \mathrm{~g})$, on the other hand, was dissolved in $75 \mathrm{ml}$ distillate water containing another amount of calculating $\mathrm{NaOH}$ under stirring until a clear solution reached (solution B). Solution (A) was added to the solution (B) to form a homogeneous state of reaction mixture; the solution $\mathrm{pH}$ was adjusted at 11 prior to vigorous stirring for $1 \mathrm{~h}$. The resulting gel was homogenized and transferred into a Teflon autoclave and allowed to react at $90{ }^{\circ} \mathrm{C}$ for 4 days. The autoclave was removed at the specific time from the furnace and quenched immediately with cold water. The solid product, thus formed was filtered and washed with distilled water until the $\mathrm{pH}$ of the filtrate dropped to 8 . The product was dried at $100{ }^{\circ} \mathrm{C}$ for $6 \mathrm{~h}$ in an oven.

Effect of aging temperature and aging time: The carefully controlled conditions of the $\mathrm{NaY}$ crystallization from the hydrous aluminosilicate amorphous gel was adopted, depending mainly on the aging temperature and aging time of the preset starting reaction gel composition: $2.76 \mathrm{Na}_{2} \mathrm{O}: 1.76 \mathrm{Al}_{2} \mathrm{O}_{3}: 2.5 \mathrm{SiO}_{2}: 125 \mathrm{H}_{2} \mathrm{O}$. Firstly, the crystallization temperature was varied between 80 and $100{ }^{\circ} \mathrm{C}$, while the aging time was kept for 4 days. Secondly, the crystallization period was varied over a range of 2 to 4 days, while the temperature was kept at $90^{\circ} \mathrm{C}$. Control of $\mathrm{pH}$ at 11 was obtained by using sodium hydroxide, where the $\mathrm{Na}^{+}$cation lead to increases dispersion of tetrahedral $\mathrm{Al}$ throughout the gel.

\section{Preparation of $\mathrm{Zn}^{\mathrm{II}}$-exchanged $\mathrm{NaY}$ zeolite}

The as-synthesized $\mathrm{NaY}$ zeolite $\left(\mathrm{SiO}_{2} / \mathrm{Al}_{2} \mathrm{O}_{3}=1.25, \mathrm{BET}=167\right.$ $\mathrm{m}^{2} / \mathrm{g}$ ) was ion-exchanged with $\mathrm{Zn}^{\mathrm{II}}$ from aqueous solution by the conventional procedure. Typically, $4.0 \mathrm{~g}$ zeolite $\mathrm{NaY}$ was treated with $1000 \mathrm{~m} 1$ of a $0.1 \mathrm{M}$ aqueous solution of zinc acetate hexahydrate $\left(\mathrm{Zn}\left(\mathrm{CH}_{3} \mathrm{COO}\right)_{2} .6 \mathrm{H}_{2} \mathrm{O}\right)$ at $50^{\circ} \mathrm{C}$ for $24 \mathrm{~h}$ with continuous stirring. The resulting suspension was filtered off, washed thoroughly with distilled water till the washing solution was essentially free of $\mathrm{Zn}^{\mathrm{II}}$ ions. The $\mathrm{Zn}^{\mathrm{II}}$-exchanged $\mathrm{Y}$ zeolite was then dried at $100^{\circ} \mathrm{C}$ and finally stored in desiccator until required for use (referred to as $\mathrm{Zn}^{\mathrm{II}} / \mathrm{Y}$ ).

\section{Preparation of $\mathrm{ZnO}$ and $\mathrm{ZnS}$ loaded into $\mathrm{NaY}$ zeolite}

A $100 \mathrm{ml}$ solution of $0.1 \mathrm{M} \mathrm{NaOH}$ or $\mathrm{Na}_{2} \mathrm{~S}$ was added dropwise to $\mathrm{Zn}^{\mathrm{II}} / \mathrm{Y}(1.5 \mathrm{~g})$ and the mixture was refluxed at $80{ }^{\circ} \mathrm{C}$ for $2 \mathrm{~h}$. The $\mathrm{Zn}(\mathrm{OH})_{2}$ or $\mathrm{ZnS}$ in $\mathrm{Y}$ zeolite thus formed was collected by filtration, washing with distilled water and followed by drying at $110^{\circ} \mathrm{C}$ for $6 \mathrm{~h}$. The products were finally calcined at $350{ }^{\circ} \mathrm{C}$ for $4 \mathrm{~h}$; the samples were denoted as $\mathrm{ZnO} / \mathrm{NaY}$ and $\mathrm{ZnS} / \mathrm{NaY}$.

\section{Antimicrobial screening}

The anti-bacterial activity of the synthesized compounds was tested against two Gram-positive bacteria: Streptococcus pneumoniae RCMB 010010, Bacillus subtilis RCMB 010067, and two Gram-negative bacteria: Pseudomonas aeruginosa RCMB 010043, Escherichia coli RCMB 010052 and two Fungal organisms: Aspergillus fumigates RCMB 02568, Candida albicans RCMB 05036.

Antimicrobial activity was determined using the agar well diffusion assay method as described by Holder and Boyce [26]. The tested organisms Escherichia coli, Bacillus subtilis and Streptococcus pneumoniae were subcultured on nutrient agar medium (Oxoid laboratories, UK) for bacteria and Saboroud dextrose agar (Oxoid laboratories, UK) for fungi. AMPICILLIN and GENTAMYCIN were used as a positive control for bacterial strains, Amphotericin B was used as a positive control for fungi. The plates were done in triplicate. Bacterial cultures were incubated at $37^{\circ} \mathrm{C}$ for $24 \mathrm{~h}$ while fungal cultures were incubated at $\left(28{ }^{\circ} \mathrm{C}\right)$ for 3-7 days. Antimicrobial activity was determined by measurement zone of inhibition in $\mathrm{mm} \pm$ standard deviation beyond well diameter $(6.0 \mathrm{~mm})$ produced on a range of environmental and clinical pathogenic microorganisms using $(10 \mathrm{mg} /$ $\mathrm{ml}$ ) concentration of testing samples. The observed zone of inhibition is presented in Table 1 .

\section{Physico-chemical characterization}

Phase identification composing the samples was analyzed with X-ray diffraction using a Philips diffractometer (type PW 3710). The patterns were run with Ni-filtered copper radiation $(\lambda=1.5404 \AA)$ at 30 $\mathrm{KV}$ and $10 \mathrm{MA}$ with a scanning speed of $2 \theta=2.5 \% \mathrm{~min}$. Crystallite size was calculated from XRD data by Scherrer equation (1) [27], in which $\mathrm{K}$ is a constant equal to $0.9, \lambda$ is the wavelength of the $\mathrm{CuK}_{\alpha}$ radiation, $\beta$ is the half peak width of the diffraction peak in radiant, and $\theta$ is the Bragg scattering angle.

$$
D=\frac{K \lambda}{\beta \cos \theta}
$$

X-ray photoelectron spectroscopy (XPS) measurements were obtained on a KRATOSAXIS 165 instrument equipped with dual aluminum-magnesium anodes using $\mathrm{MgK}_{\alpha}$ radiation as the $\mathrm{X}$-ray source at a power of $150 \mathrm{~W}$ (accelerating voltage $12 \mathrm{KV}$, current $6 \mathrm{MA}$ ) in a vacuum of $8.0 \times 10^{-8} \mathrm{mpa}$. The measured samples were prepared by dropping a concentrated colloidal solution (derived from centrifugation and redispersion of the as-synthesized zeolite suspension) on freshly cleaved HOPG and drying at room temperature. 


\begin{tabular}{|l|l|l|l|}
\hline Samples Tested Microorganism & NaY & ZnO/NaY & ZnS/NaY \\
\hline Fungi & & & Standard \\
\hline Aspergillus fumigates (RCMB 02568) & NA & NA & Amphotericin B \\
\hline Candida albicans (RCMB 05036) & NA & NA & NA \\
\hline Gram-positive-bacteria & & $14.3 \pm 0.63$ & $16.4 \pm 0.44$ \\
\hline Streptococcus pneumoniae (RCMB 010010) & $13.4 \pm 0.58$ & $20.6 \pm 0.44$ & $22.3 \pm 0.63$ \\
\hline Bacillus subtilis (RCMB 010067) & $19.3 \pm 0.58$ & & Ampicillin \\
\hline Gram-negative-bacteria & & NA & NA \\
\hline Pseudomonas aeruginosa RCMB 010043 & NA & $19.2 \pm 0.63$ & $32.4 \pm 0.3$ \\
\hline Escherichia coli RCMB 0010052 & $17.4 \pm 0.63$ & $20.5 \pm 0.58$ \\
\hline
\end{tabular}

The test was done using the diffusion agar technique, well diameter $6.0 \mathrm{~mm}$ (100 $\mu \mathrm{l}$ was tested), RCMB: Regional Center for Mycology and Biotechnology Antimicrobial; Unit test organisms: NA=No activity, data are expressed in the form of mean \pm SD.

Table 1: Anti-microbial activity of the synthesized NaY and modification with Zinc nanoparticles.

Fourier transform infrared (FT-IR) spectra were recorded on a Perkin Elmer Spectrometer (RXI FT-IR) system, single beam with a resolution of $2 \mathrm{~cm}^{-1}$. The samples were ground with $\mathrm{KBr}$ $(1: 100)$ as a tablet and mounted to the sample holder in the cavity of the spectrometer. The measurements were recorded at the room temperature in the region $4000-400 \mathrm{~cm}^{-1}$. Size and particle morphology of the $\mathrm{Zn} / \mathrm{NaY}$ crystals were determined using the scanning electron micrographs obtained on a JEOL scanning microscope model JSM-T $330 \mathrm{~A}$ at an accelerating voltage of $30 \mathrm{KV}$.

\section{Results and Discussion}

\section{XRD patterns of as-synthesized $\mathrm{NaY}$ zeolite}

In Figure 1 shows the XRD patterns of samples made with different $\mathrm{Na}_{2} \mathrm{O} / \mathrm{SiO}_{2}$ molar ratios $(\mathrm{Na} / \mathrm{Si}=0.69-1.01)$ in the gel composition. At a low $\mathrm{Na}_{2} \mathrm{O} / \mathrm{SiO}_{2}$ molar ratio of 0.69 , amorphous sodium aluminosilicate hydrate than the zeolite phase appeared at $2 \theta$ of $21.644^{\circ}$ and $28.076^{\circ}$ (Figure 1a). When the $\mathrm{Na}_{2} \mathrm{O} / \mathrm{SiO}_{2}$ molar ratio increased from 0.69 to 0.86 , reflection peaks observed at $2 \theta$ of $14.383^{\circ}, 8.88^{\circ}, 7.52^{\circ}, 5.71^{\circ}, 3.8^{\circ}$, $3.33^{\circ}$ and $2.87^{\circ}$ correspond to the pure zeolite $\mathrm{NaY}$, in agreement with the JCPDS file No. 71-0962. Therefore, this adopted $\mathrm{Na}_{2} \mathrm{O} / \mathrm{SiO}_{2}$ molar ratio in the synthesis gel composition is beneficial for the formation of a single phase of zeolite $\mathrm{NaY}$ since the realization of foreign phases is suppressed. Therefore, $\mathrm{Na}^{+}$plays a crucial role not only as charge balancing agent for negatively charged $\mathrm{AlO}_{4}$ in the crystalline framework, but rather may act as a template assisted species in the incorporation of $\mathrm{Al}$ atoms into the zeolite framework. Our results are in agreement with those reported in [28] that reveal $\mathrm{Na}^{+}$affects the dissolution and polymerization-depolymerization reactions of silicates and aluminosilicates [28]. Further increase in this ratio from 0.86 to 1.01 results in a change of zeolite phase from $\mathrm{NaY}$ to zeolite-X and zeolite $\mathrm{P}_{2}$ as shown in (Figure 1c). The dependence of $\mathrm{NaY}$ formation on the hydrothermal temperature in the range between 80 and $100{ }^{\circ} \mathrm{C}$ is thoroughly investigated using fixed molar ratios in the initial gel composition, i.e. $\mathrm{SiO}_{2} / \mathrm{Al}_{2} \mathrm{O}_{3}=1.25$ and $\mathrm{Na}_{2} \mathrm{O} / \mathrm{SiO}_{2}=0.86$ (Figure 2). The $\mathrm{NaY}$ zeolite is formed in almost amorphous characteristics at 80 ${ }^{\circ} \mathrm{C}$, while a sole crystalline phase of $\mathrm{NaY}$ zeolite can be seen with notably high degree of crystallinity at $90^{\circ} \mathrm{C}$. As the temperature increased to 100 ${ }^{\circ} \mathrm{C}$, the crystallinity of the $\mathrm{NaY}$ zeolite particles diminishes compared with that hydrothermally treated at $90^{\circ} \mathrm{C}$. Concurrently a new phase of zeolite $\mathrm{A}$ is observed mainly as a consequence of increasing of solubility of aluminate and silicate species, causing a shift in the concentration of the liquid phase [29].

The effect of aging time on the crystallization of $\mathrm{NaY}$ zeolite with the same gel composition and then brought to the hydrothermal temperature of $90^{\circ} \mathrm{C}$ is shown in Figure 3. It was found that a mixture of zeolites $\mathrm{Y}$ and $\mathrm{A}$ appeared in a shorter crystallization time as two days, whereas a maximal crystallinity of pure $\mathrm{NaY}$ is reached in four days, From the literature, it is known that the $\mathrm{Si} / \mathrm{Al}$ ratio for zeolite $\mathrm{Y}$ is higher than zeolite A $[30,31]$. The crystallization time lower as two days is probably insufficient to dissolve amorphous silica and thus some low-solubility sodium aluminosilicate compounds (e.g. $\mathrm{Na}_{2} \mathrm{SiO}_{3}$, $\left.\mathrm{Na}\left[\mathrm{Al}\left(\mathrm{SiO}_{3}\right)_{2}\right]\right)$ are formed during heat treatment.

\section{$\mathrm{X}$-ray diffraction of $\mathrm{ZnO} /$ and $\mathrm{ZnS} / \mathrm{NaY}$ zeolite}

The Figure 4 shows the XRD patterns of the successfully synthesized $\mathrm{NaY}$ zeolite and after loading $\mathrm{ZnO}$ and $\mathrm{ZnS}$. All the samples gave the typical peaks of the $\mathrm{NaY}$ zeolite structure, which also showed they had good crystallinity. Therefore, the intrinsic structure of the $\mathrm{NaY}$ zeolite remained basically intact at this stage of $\mathrm{Zn}$ loading. No crystalline feature characteristic of a separated $\mathrm{ZnO}$ or $\mathrm{ZnS}$ phase in the patterns of $\mathrm{ZnO} /$ and $\mathrm{ZnS} / \mathrm{NaY}$ was detected, implying a homogeneous distribution of zinc ${ }^{\mathrm{II}}$ as small $\mathrm{ZnO}$ or $\mathrm{ZnS}$ oligomers either in the pores or nearby zeolite surface. This species will tend to become uniform throughout the internal zeolite surface, except perhaps inside cavities in which the steric hindrance effects may be important. This was clarified as an increase in the lattice constant $a$ from $24.915 \AA$ for NaY to 24.939 and $24.979 \AA ̊$ for $\mathrm{ZnS} /$ and $\mathrm{ZnO} / \mathrm{NaY}$, respectively (Table 2).

It has been shown previously that the incorporated cations are randomly distributed within the $\mathrm{Y}$ lattice if $\mathrm{I}_{331}>\mathrm{I}_{220}>\mathrm{I}_{311}$, but if $\mathrm{I}_{331}$ $>\mathrm{I}_{311}>\mathrm{I}_{220}$, the cations assume positions at sites I, II [32,33]. It may be seen from Figure 4, that $\mathrm{Zn}^{\text {II }}$ displaced primarily sodium ions from their random positions within the lattice upon incorporation of $\mathrm{ZnO}$ into $\mathrm{NaY}$ is assumed. Conversely, analysis of the $\mathrm{ZnS} / \mathrm{NaY} \mathrm{XRD}$ pattern indicates that a significant cation redistribution occurred following the $\mathrm{ZnS}$ incorporation has taken place. This is an indication that the slightly larger sizes of the $\mathrm{ZnS}$ molecules displaced sodium ions from their random positions to locations at the sites I, II. A site $\mathrm{I}^{-}$, is located apparently in the sodalite cavity while site II at the center of a single sixring (S6R) or displaced from this point into a super cage.

\section{Surface properties}

The $\mathrm{N}_{2}$ adsorption-desorption isotherms of $\mathrm{NaY}, \mathrm{ZnO} / \mathrm{NaY}$ and $\mathrm{ZnS} / \mathrm{NaY}$ samples are shown in Figure 5. They all exhibit type II

\begin{tabular}{|l|l|l|l|l|}
\hline Samples & $\begin{array}{l}\text { Crystal size } \\
(\mathbf{n m})\end{array}$ & $\begin{array}{l}\text { Unit cell } \\
\mathbf{a}(\mathbf{A})\end{array}$ & $\begin{array}{l}\text { Cell volume } \\
\left(\mathbf{A}^{3} \mathbf{)}\right.\end{array}$ & $\begin{array}{l}\text { Crystallinity } \\
\%\end{array}$ \\
\hline $\mathrm{NaY}$ zeolite & 33 & 24.915 & 15466 & 68 \\
\hline $\mathrm{ZnO} / \mathrm{NaY}$ & 21 & 24.979 & 15586 & 100 \\
\hline $\mathrm{ZnS} / \mathrm{NaY}$ & 18 & 24.939 & 15511 & 77 \\
\hline
\end{tabular}

Note: $a$ is the lattice parameter. The crystallinity percentages (\%) were obtained by $\mathrm{XRD}$ from the sum of the maximum line intensities.

Table 2: Effect of modification $\mathrm{NaY}$ zeolite by $\mathrm{ZnO}$ or $\mathrm{ZnS}$ on the particles size, unit cell parameters and crystallinity of the investigated solids. 


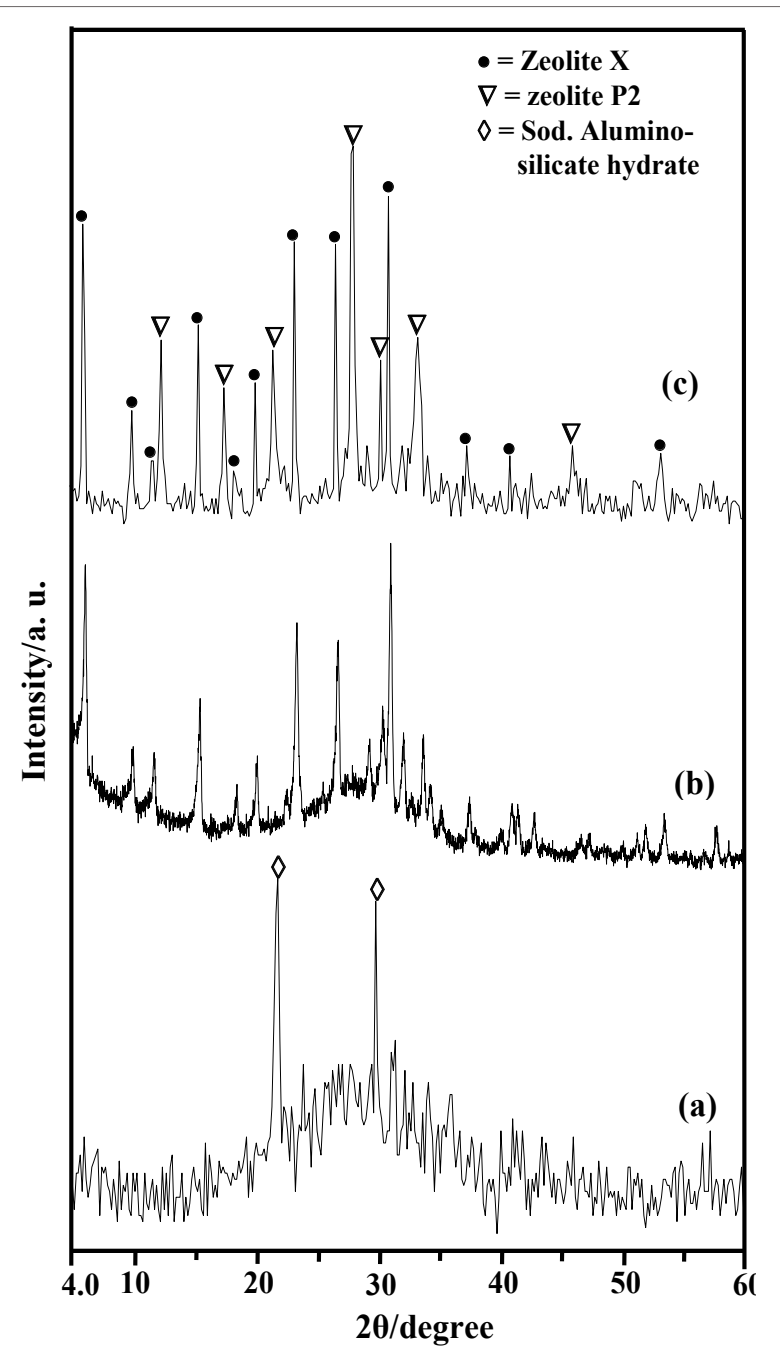

Figure 1: X-ray diffractograms of $\mathrm{NaY}$ zeolite synthesized as a function of increasing $\mathrm{Na}_{2} \mathrm{O} / \mathrm{SiO}_{2}$ molar ratios; where (a) $\mathrm{Na}_{2} \mathrm{O} / \mathrm{SiO}_{2}=0.69$, (b) $\mathrm{Na}_{2} \mathrm{O} /$ $\mathrm{SiO}_{2}=0.86$ and (c) $\mathrm{Na}_{2} \mathrm{O} / \mathrm{SiO}_{2}=1.01$

isotherm characteristics of macroporous type of pores. However, this macroporosity is not only reflected from the hysteresis loops, but rather indicate mesoporosity character. Accordingly, this macroporosity evidenced from the non-saturation at $\mathrm{p} / \mathrm{p}_{\mathrm{o}}=0.95$ could be acquired from the left distances occurred between particles during interaction. Hysteresis formed in pore networks is perfect with $\mathrm{H}_{3}$ hysteresis that does not exhibit any limiting adsorption at high $P / P^{0}$. This behaviour can for instance be caused by the existence aggregated particles in the pores. The hysteresis cycle of $\mathrm{ZnS} / \mathrm{NaY}$ indicates a developed mesoporosity compared with that of $\mathrm{ZnO} / \mathrm{NaY}$. In this sense, evidence for the growth of sulfide particles within the zeolite lattice to sizes exceeding the dimension of the supercage can be obtained. This led to the creation of mesopores in $\mathrm{ZnS} / \mathrm{NaY}$ due to local destruction of the zeolite lattice around the growing particles.

The pore size distribution curves displayed a unimodal type of pores covering the range from 10 to $30 \AA$ in $\mathrm{NaY}$ with a maximum distribution at $15 \AA$ where that of $\mathrm{ZnO} / \mathrm{NaY}$ indicates a maximum of 13 $\AA$ displayed in the range from 10 to $40 \AA$. On the other hand, $\mathrm{ZnS} / \mathrm{NaY}$ indicates bimodal distribution at 10 and $45 \AA$ highlighting the increase of the microporosity of this sample comparatively.
The BET surface area, pore volume and pore diameter of synthesized samples are given in Table 3 . The surface area of zeolite samples follows the order: $\mathrm{NaY}>\mathrm{ZnS} / \mathrm{NaY}>\mathrm{ZnO} / \mathrm{NaY}$, however the pore volume was in the order: $\mathrm{ZnS} / \mathrm{NaY}>\mathrm{NaY}>\mathrm{ZnO} / \mathrm{NaY}$. The reduction in the surface area of $\mathrm{ZnO} / \mathrm{NaY}(48 \%)$ and $\mathrm{ZnS} / \mathrm{NaY}$ (14\%) compared to parent $\mathrm{NaY}$ is indicative of the well incorporation $\mathrm{ZnO}$ and $\mathrm{ZnS}$ inside the pores of $\mathrm{NaY}$ substrate and indeed proportional to the amount of either $\mathrm{ZnO}$ or $\mathrm{ZnS}$ blocking the zeolite $\mathrm{NaY}$ pores. In addition, it seems that $\mathrm{ZnO} / \mathrm{NaY}$ stimulates the existence of microporosity as evidenced from notifying that the desorption part closed at $\mathrm{P} / \mathrm{P}_{0}=0.17$ with that of the adsorption one (see also Table 3). However, this is contradicted the decrease in $\mathrm{S}_{\mathrm{BET}}$ of this sample compared to that of $\mathrm{ZnS} / \mathrm{NaY}$; based on the thought that the increase in surface area is a function of microporosity but indeed gives a hint about the strong interaction between them. Increasing the computed value of the pore radius ( $\mathrm{r}$ ) of $\mathrm{ZnS} / \mathrm{NaY}$ when compared with the rest of investigating samples indicates the enforced location of $\mathrm{ZnS}$ species inside zeolite pores causing an enlargement. This could give a hint about accommodating zinc sulfide particles in micropores and thus caused the expansion in unit cell (as depicted from XRD) and pore size. This is collaborated to the marked decrease in crystallinity of $\mathrm{ZnS} / \mathrm{NaY}$ compared to $\mathrm{ZnO} / \mathrm{NaY}$, due to internal perturbations influence the final state of $\mathrm{NaY}$ zeolite.

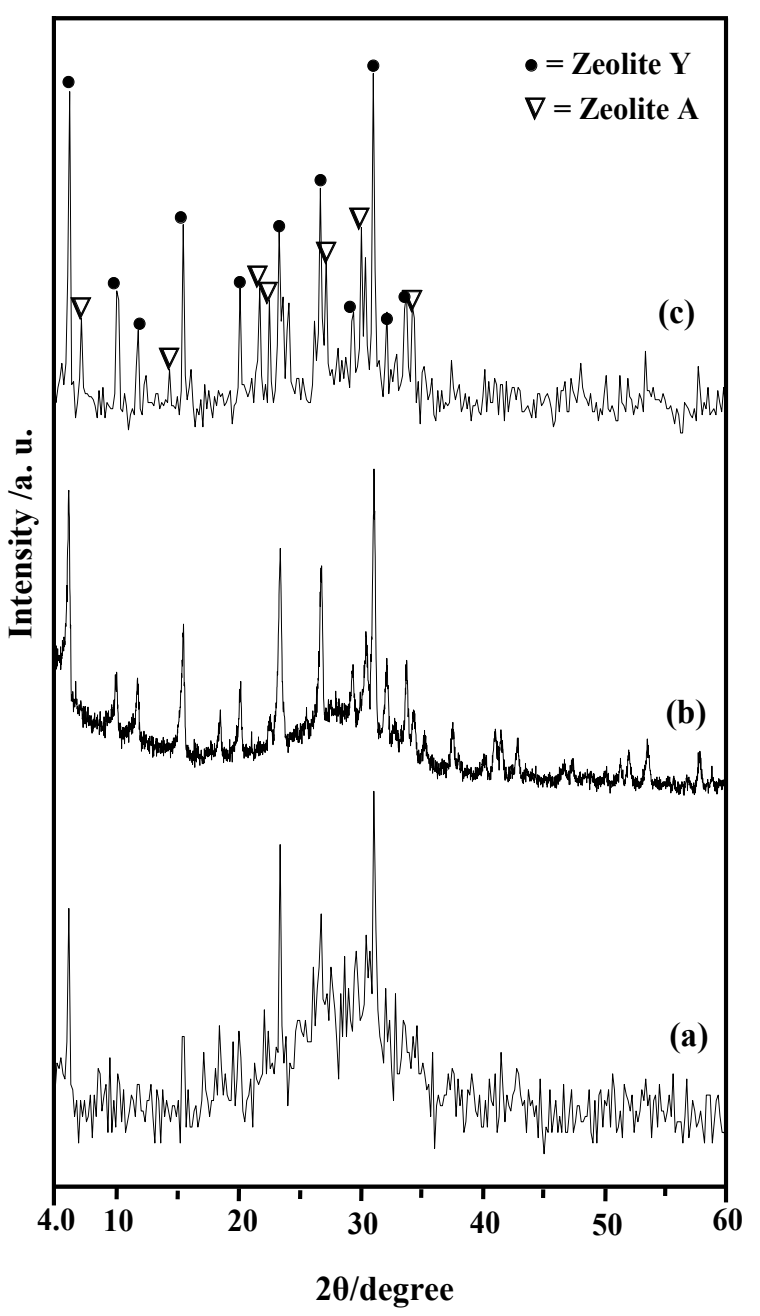

Figure 2: X-ray diffraction patterns of $\mathrm{NaY}$ zeolite synthesized as a function of hydrothermal temperature; where (a) $80^{\circ} \mathrm{C}$, (b) $90^{\circ} \mathrm{C}$ and (c) $100^{\circ} \mathrm{C}$. 


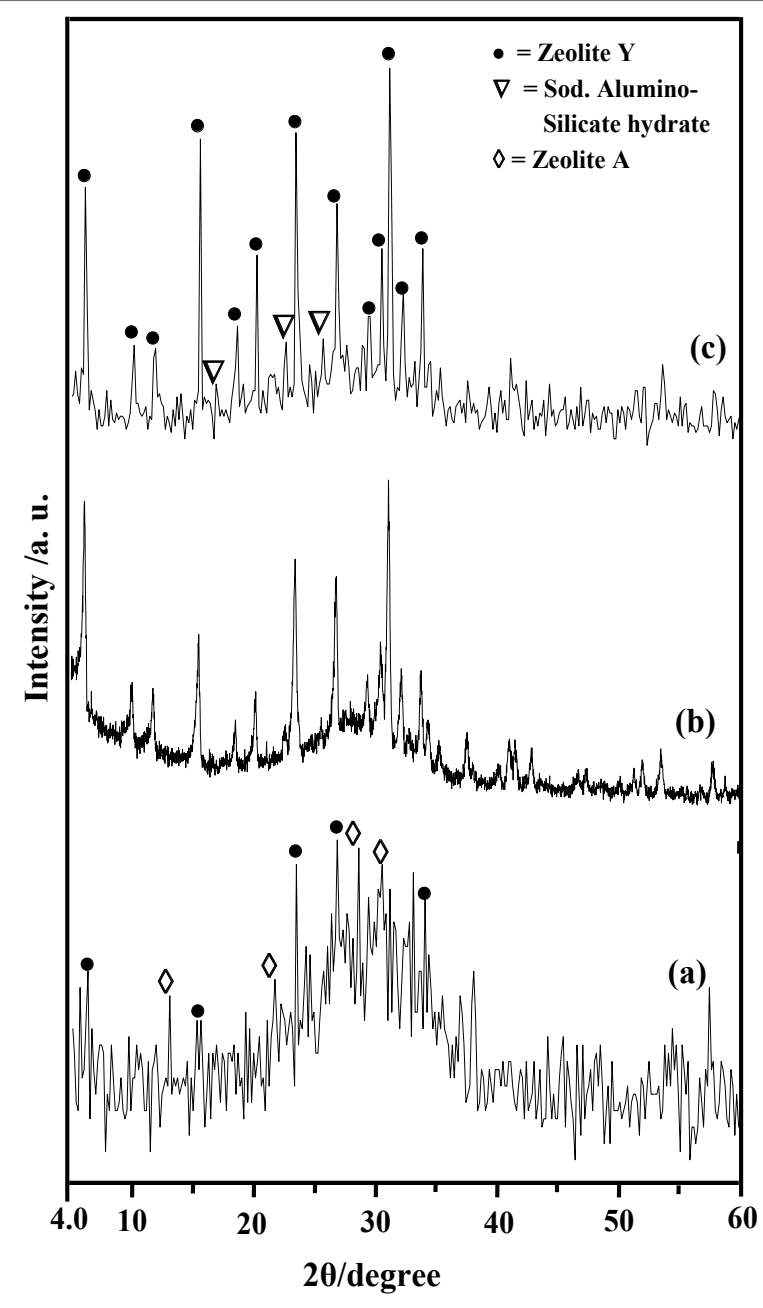

Figure 3: X-ray diffraction patterns of $\mathrm{NaY}$ zeolite synthesized as a function of hydrothermal time; where (a) 2 days, (b) 4 days and (c) 5 days.

\begin{tabular}{|c|c|c|c|c|c|c|c|c|c|}
\hline Sample & $\begin{array}{l}S_{\text {BEE }} \\
\left(m^{2} / g\right)\end{array}$ & $\begin{array}{l}S_{\mathrm{t}} \\
\left(\mathrm{m}^{2} / \mathrm{g}\right)\end{array}$ & $\begin{array}{l}S^{\mu} \\
\left(m^{2} / g\right)\end{array}$ & $\begin{array}{l}S^{e x t} \\
\left(m^{2} / g\right)\end{array}$ & $\begin{array}{l}r \\
\text { (A) }\end{array}$ & $\begin{array}{l}\mathrm{Vp}_{\text {total }} \\
\left(\mathrm{cm}^{3} / \mathrm{g}\right)\end{array}$ & $\begin{array}{l}V_{p}{ }_{p} \\
\left(\mathbf{c m}^{3} / g\right)\end{array}$ & $\begin{array}{l}V_{p} \text { wid } \\
\left(\mathrm{cm}^{3} / g\right)\end{array}$ & $\begin{array}{l}\text { Micro. } \\
\%\end{array}$ \\
\hline $\mathrm{NaY}$ & 167 & 173 & 111 & 56 & 19.6 & 0.163 & 0.061 & 0.102 & 37 \\
\hline $\mathrm{ZnO} / \mathrm{NaY}$ & 87 & 86 & 57 & 30 & 17.4 & 0.075 & 0.030 & 0.045 & 40 \\
\hline $\mathrm{nS} / \mathrm{NaY}$ & 144 & 104 & 65 & 79 & 24.1 & 0.174 & 0.037 & 0.137 & 21 \\
\hline
\end{tabular}

Note: $\left(\mathrm{S}_{\mathrm{BET}}\right)$ BET-surface area; $\left(\mathrm{S}_{\mathrm{t}}\right)$ surface area derived from $\mathrm{V}_{1-\mathrm{t}}$ plots; ( $\mathrm{S}^{\mathrm{ext}}$ external surface area; $\left(S^{\mu}\right)$ surface area of micropores; ( $\left.{ }^{\text {wid }}\right)$ surface area of wide pores; $\left(V_{p}^{\text {total }}\right)$ total pore volum $\left(V_{p}{ }^{\mu}\right)$ pore volume of micropores; $(r)$ mean pore radius

Table 3: Surface characteristics of $\mathrm{NaY}, \mathrm{ZnO} / \mathrm{NaY}$ and $\mathrm{ZnO} / \mathrm{NaY}$ investigated by thermal treatment at $200{ }^{\circ} \mathrm{C}$ under reduced pressure of $10^{-5}$ Torr and nitrogen adsorption at $-196{ }^{\circ} \mathrm{C}$

\section{FT-IR spectra of $\mathrm{ZnO} / \mathrm{NaY}$ zeolite}

The infrared spectra of the as-synthesized $\mathrm{NaY}$ zeolite, $\mathrm{ZnO} /$ and $\mathrm{ZnS} / \mathrm{NaY}$ in the $1400-400 \mathrm{~cm}^{-1}$ range are shown in Figure 6 . The infrared spectrum for the as-synthesized $\mathrm{NaY}$ zeolite shows significant peaks from 1400 to $400 \mathrm{~cm}^{-1}$, compared to the relevant spectrum assigned by Flanigen and Khatami [34,35]. The absorption bands at $1034\left(v_{\mathrm{as}}\right)$, $707\left(v_{s}\right)$ and $452 \mathrm{~cm}^{-1}$ are three lattice modes associated with internal vibrations of the $(\mathrm{Si}, \mathrm{Al}) \mathrm{O}_{4}$ tetrahedral unit which designated as $\mathrm{TO}_{4}$ in the framework of $Y$ zeolite and are structure-insensitive. The structure- sensitive vibrations due to external linkages between tetrahedra are found at $1158\left(v_{\text {as }}\right)$ and $584 \mathrm{~cm}^{-1}$ due to double 6-rings (D6Rs).

The vibrational spectra of $\mathrm{ZnO} /$ and $\mathrm{ZnS} / \mathrm{NaY}$ had distinguished spectral effects relative to that of as-synthesized $\mathrm{NaY}$, in which the bands of $\mathrm{TO}_{4}$ units become progressively larger and are down shifted from 1034 to 994 and $1006 \mathrm{~cm}^{-1}$, respectively. This is in good agreement with the literature [36], suggesting the preferential substitution of some $\mathrm{Si}^{\mathrm{IV}}$ in the framework by $\mathrm{Al}^{\mathrm{III}}$ leaving a net negative charge which is balanced by the extra framework $\mathrm{Zn}^{\mathrm{II}}$. It has been shown $[37,38]$ that bonding of divalent cations to the framework oxygen atoms causes local deformation of the zeolite framework, which may be detected in $\mathrm{T}-\mathrm{O}-\mathrm{T}$ vibration changes. $\mathrm{ZnO} / \mathrm{NaY}$ caused local deformation of the vibrational band at $707 \mathrm{~cm}^{-1}$; it was splitted into 750 and $696 \mathrm{~cm}^{-1}$ where the former represents the $\mathrm{Zn}-\mathrm{O}$ vibration [39]. This effect is not apparent in case of $\mathrm{ZnS} / \mathrm{NaY}$. It has been reported that zinc cations are best stabilized when the divalent charge is directly balanced by two framework $\mathrm{Si}-\mathrm{O}^{-}-\mathrm{Al}$ groups, that is, coordinated to 6-membered rings of oxygen atoms, as well as in a second site consisting of $[\mathrm{Zn}-\mathrm{O}-\mathrm{Zn}]^{2+}$ balanced by aluminum atoms which are further apart [40]. On the contrary, a new hump at $621 \mathrm{~cm}^{-1}$ assigned to $\mathrm{Zn}-\mathrm{S}$ stretching vibration [41] could be seen in the spectrum of $\mathrm{ZnS} / \mathrm{NaY}$.



Figure 4: X-ray diffraction patterns of $\mathrm{NaY}$ zeolite modification by Zinc as oxide or sulphide; where (a) $\mathrm{NaY}$, (b) $\mathrm{ZnO} / \mathrm{NaY}$ and (c) $\mathrm{ZnS} / \mathrm{NaY}$. 


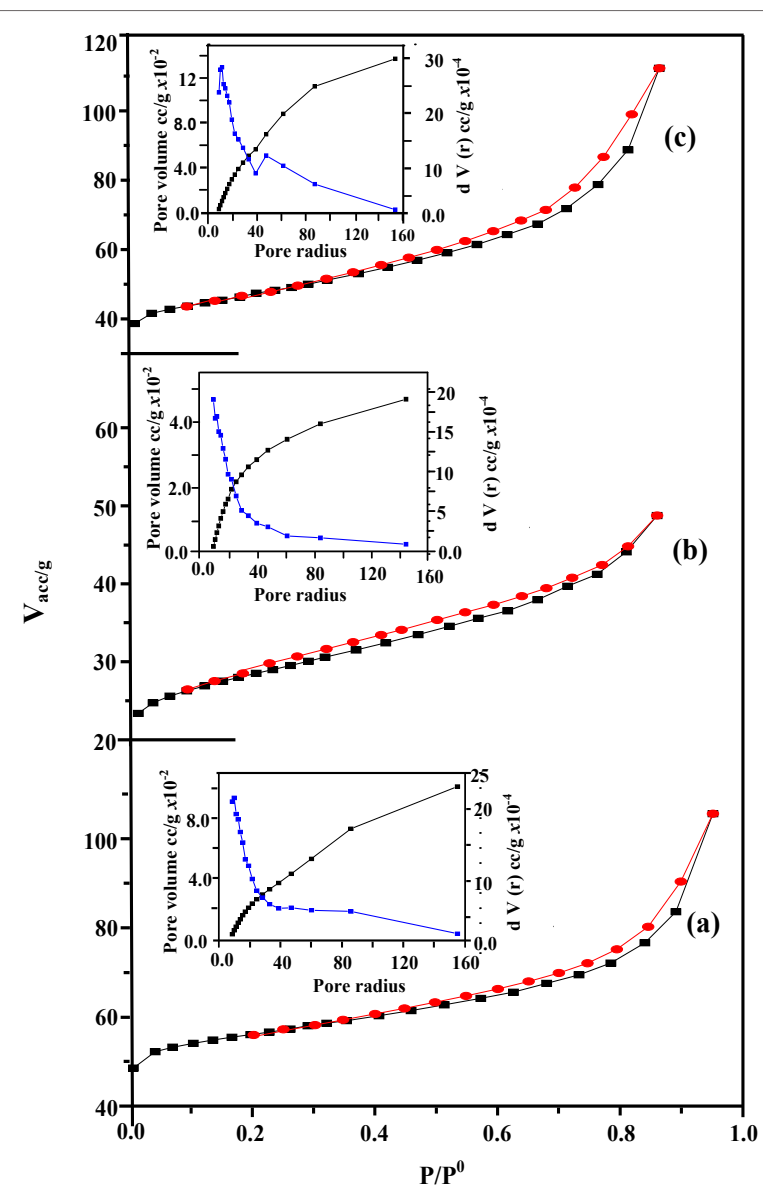

Figure 5: $\mathrm{N}_{2}$ adsorption-desorption isotherms and corresponding pore size distribution curves of (a) $\mathrm{NaY}$, (b) $\mathrm{ZnO} / \mathrm{NaY}$ and (c) $\mathrm{ZnS} / \mathrm{NaY}$ samples calcined in air at $350^{\circ} \mathrm{C}$.

The $3740 \mathrm{~cm}^{-1}$ band is assigned to surface isolated silanol $(\mathrm{SiOH})$ groups [41]; that at $3677 \mathrm{~cm}$ is associated with hydroxyl groups attached to extra-framework $\mathrm{T}$ atom-containing species [42]. The doublet at 3620 and $3550 \mathrm{~cm}^{-1}$ in the spectrum of NaY (Figure 6a), assigned to bridging hydroxyl (SiOHAl) groups, became narrower and shifted to lower frequencies in the spectra of $\mathrm{ZnO} / \mathrm{NaY}$ and $\mathrm{ZnS} /$ $\mathrm{NaY}$, i.e. 3614 and $3550 \mathrm{~cm}^{-1}$ for the former and 3610 and $3531 \mathrm{~cm}^{-1}$ for the latter. These effects might suggest that aluminum atoms are preferentially moved from octahedral to tetrahedral positions by the modification with zinc species, and the formation of phase composite materials by $\mathrm{NaY}$ lattice interacting with zinc ions as well. The band at $3531 \mathrm{~cm}^{-1}$ in $\mathrm{ZnS} / \mathrm{NaY}$ (Figure 6c) is significantly diminished and thus may be related to framework bridging hydroxyl groups in sodalite cages, suggesting that the zinc sulfide are mainly located at SiOHAl.

\section{$\mathrm{X}$-ray photoelectron spectra of $\mathrm{ZnO}$ and $\mathrm{ZnS} / \mathrm{NaY}$}

The state(s) of zinc ion in direct contact with the NaY lattice has been provided through $\mathrm{Zn} 2 \mathrm{p}$ core-level XPS spectra of $\mathrm{ZnO} / \mathrm{NaY}$ and $\mathrm{ZnS} / \mathrm{NaY}$ (Figure 7). The $\mathrm{ZnS} / \mathrm{NaY}$ spectrum exhibits the high intensity $\mathrm{Zn} 2 \mathrm{p} 1 / 2$ and $\mathrm{Zn} 2 \mathrm{p} 3 / 2$ peaks at 1049.21 and $1026.45 \mathrm{eV}$, respectively. This indicates that the $\mathrm{BE}$ peaks of $\mathrm{Zn}$ in $\mathrm{NaY}$ have been found in the +2 valence state [43-46]. Nevertheless, these peaks are shifted to lower BEs in $\mathrm{ZnO} / \mathrm{NaY}$, i.e. 1047.94 and $1024.84 \mathrm{eV}$, suggesting the presence of $\mathrm{ZnO}$ like structures in isolated sites. However, $\mathrm{Zn} 2 \mathrm{p}$ states in $\mathrm{ZnO}$ are observed at lower BEs compared to those of the corresponding peaks of $\mathrm{ZnS}$ [47].
Analysis of the $\mathrm{S} 2 \mathrm{p}$ peak of $\mathrm{ZnS} / \mathrm{NaY}$ reveals the existence of several sulfur species as shown in Figure 8. Deconvolution results shown in the same Figure indicate two dissymmetric doublet states; the first doublet at 168.43 and $167.78 \mathrm{eV}$ may suggest a thin layer of $-\mathrm{Zn}-\mathrm{O}-\mathrm{S}$ - cluster and the second one at 159.69 and $158.85 \mathrm{eV}$ leading to the sulfur states in zinc sulfide [48]. Any noticeable oxidized sulfur species (e.g. $-\mathrm{SO}_{2}$ ) not detected. The atomic percentages of $\mathrm{Zn}$ and $\mathrm{S}$ were also calculated from XPS peak areas of the relevant elements. The $S / Z n$ ratio was found to be 1.0074 , indicating the stoichiometric ratio of $\mathrm{ZnS}$.

\section{Particle morphology of $\mathrm{ZnO}$ and $\mathrm{ZnS} / \mathrm{NaY}$}

The effects on the crystal morphology as well as on the aggregation of the crystals have been investigated with SEM and the micrographs of different samples are shown in Figure 9a-c. The particles of assynthesized $\mathrm{NaY}$ form larger aggregates, which are composed of many smaller individual zeolite particles. Because of the agglomeration of the particles, it is difficult to determine the primary particle size only based on the SEM image. On the other hand, the brighter and foamy aggregated particles observed in the SEM images of $\mathrm{ZnO}$ and $\mathrm{ZnS} / \mathrm{NaY}$ illustrate the presence of newly formed phase on the zeolite surface. It is likely that the $\mathrm{ZnS} / \mathrm{NaY}$ sample shows inhomogeneous particles which gave rise to intercrystalline voids. These macropores are mainly contributed to the sulfide clusters created within the lattice structure of $\mathrm{NaY}$ zeolite, in compatible with the surface characteristics data. These intercrystalline voids are not apparent in the micrograph of $\mathrm{ZnO} / \mathrm{NaY}$ sample.

\section{Biological activity}

The antimicrobial activities of the various samples were investigated for selected microorganisms (Table 1 and Figure 10). The tested microorganism strains were: (Gram-positive bacteria: Streptococcus pneumoniae RCMB 010010, Bacillus subtilis RCMB 010067, and two Gram- negative bacteria: Pseudomonas aeruginosa RCMB 010043, Escherichia coli RCMB 010052 and two Fungal organisms: Aspergillus fumigates RCMB 02568, Candida albicans RCMB 05036) and the results of antimicrobial activity values and zone of inhibition are shown in
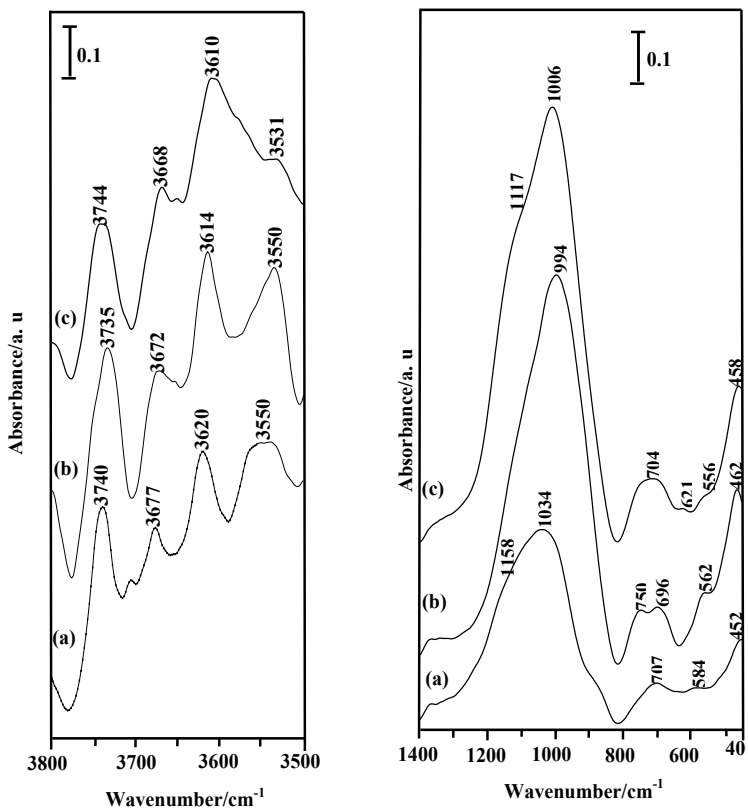

Figure 6: FT-IR spectra of NaY zeolite modification by Zinc as oxide or sulphide where (a) $\mathrm{NaY}$ (b) $\mathrm{ZnO} / \mathrm{NaY}$ and (c) $\mathrm{ZnS} / \mathrm{NaY}$. 


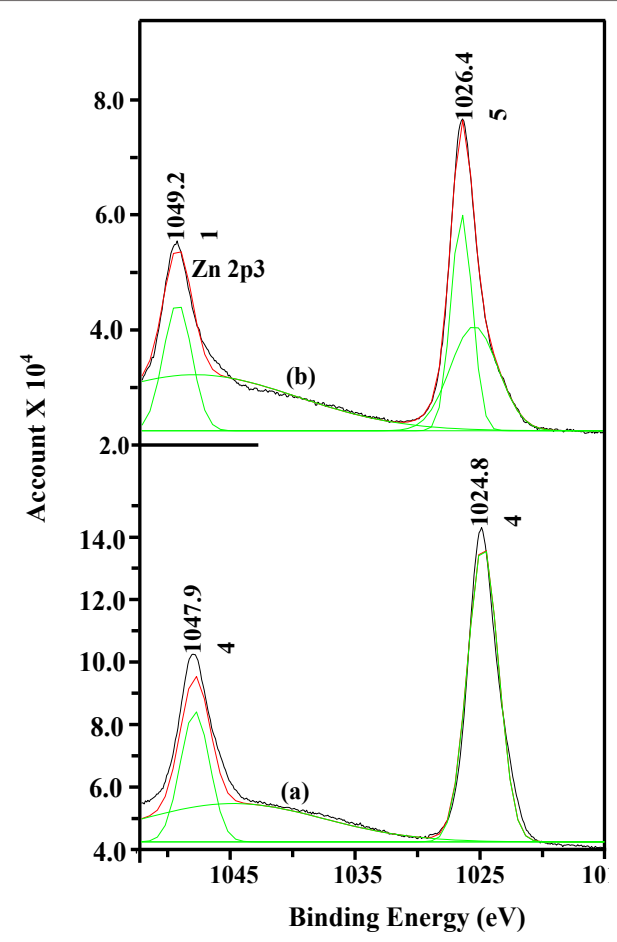

Figure 7: Peak fitting of $\mathrm{Zn} 2 \mathrm{p}^{3}$ spectra of (a) $\mathrm{ZnO} / \mathrm{NaY}$ and (b) $\mathrm{ZnS} / \mathrm{NaY}$.

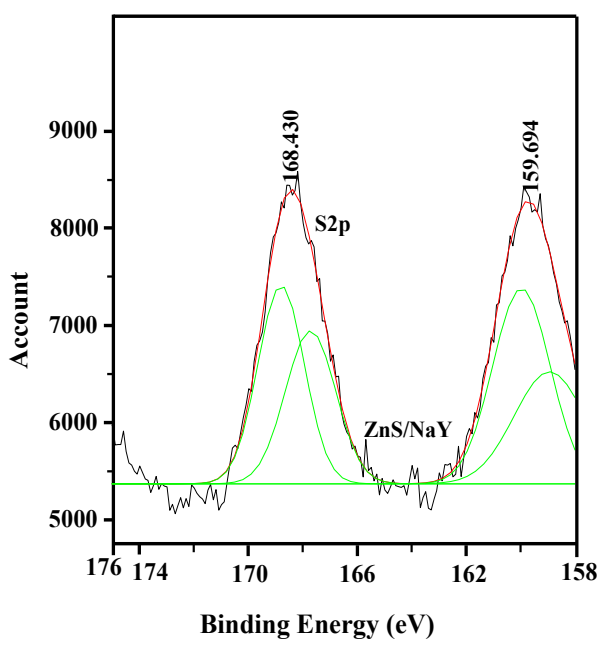

Figure 8: Peak fitting of S2p spectra of $\mathrm{ZnS} / \mathrm{NaY}$.

Table 1 and Figure 10. The Table 1 reports the following information: (i) The Gram- positive bacteria on as-synthesized $\mathrm{NaY}, \mathrm{ZnO} / \mathrm{NaY}$ and $\mathrm{ZnS} / \mathrm{NaY}$ exhibite moderate activity on Streptococcus pneumonia and Bacillus subtilis when compared with the activity of AMPICILLIN; however, their activities increased gradually as follows: $\mathrm{NaY}<\mathrm{ZnO} / \mathrm{NaY}$ $<\mathrm{ZnS} / \mathrm{NaY}$. (ii) The $\mathrm{ZnS} / \mathrm{NaY}$ sample showed considerably superior antibacterial activity when compared with $\mathrm{ZnO} / \mathrm{NaY}$, especially against Escherichia coli when compared with GENTAMYCIN.

Regarding the mechanism of antibacterial activity of the zeolitic materials, gram negative bacteria showed more inhibition zone than the gram positive bacteria due to the cell wall nature of the bacteria. The gram positive bacteria formation of the cell wall is collected of deep layers of membrane, consisting of linear polysaccharide chains, and the gram negative bacteria possess the slender layer of membrane. Vanaja et al. [49] reported that gram positive bacteria have thick and chemically complex peptidoglycan in the cell wall, and therefore the zeolitic materials did not easily taken up into the cell. Contrary to this, gram negative bacteria have thin and simple multilayered lipid components in the cell wall, so that the zeolitic particles did easily enter into bacterial cells, and thus showed an inhibition zone higher than the gram positive bacteria. Rajeshkumar et al. [50] reported that microbes transmit a positive charge in which it results in an electromagnet attraction between the microorganisms and the bacterial outer cell membrane. The present study demonstrates that $\mathrm{ZnS} / \mathrm{NaY}$ possesses bactericidal activity against the entire test organism.

In vitro antifungal studies, all synthesized composites were tested against Aspergillus fumigates RCMB 02568, Candida albicans RCMB 05036) and the antifungal and activity are presented in Table 1. In general, all the synthesized composites displayed exerted inactivation in vitro antifungal activity against the tested organism.

\section{Conclusion}

Amorphous silica extracted from waste RHs was found to be reactive towards the formation of $\mathrm{NaY}$ zeolite. This means that more cations were added in the form of $\mathrm{NaOH}$, resulting in the concentration of $\mathrm{OH}^{-}$being controlled simultaneously by the concentration of cations. The pure $\mathrm{NaY}$ phase has been produced with the $\mathrm{Na}_{2} \mathrm{O} / \mathrm{SiO}_{2}$ molar ratio of 0.86 in the synthesis gel followed by isothermal crystallization at 90 ${ }^{\circ} \mathrm{C}$ for 4 days under autogenous pressure. The incorporation of $\mathrm{ZnO}$ into the structure of $\mathrm{NaY}$ suggested that the zeolite retained $\mathrm{ZnO}$ as
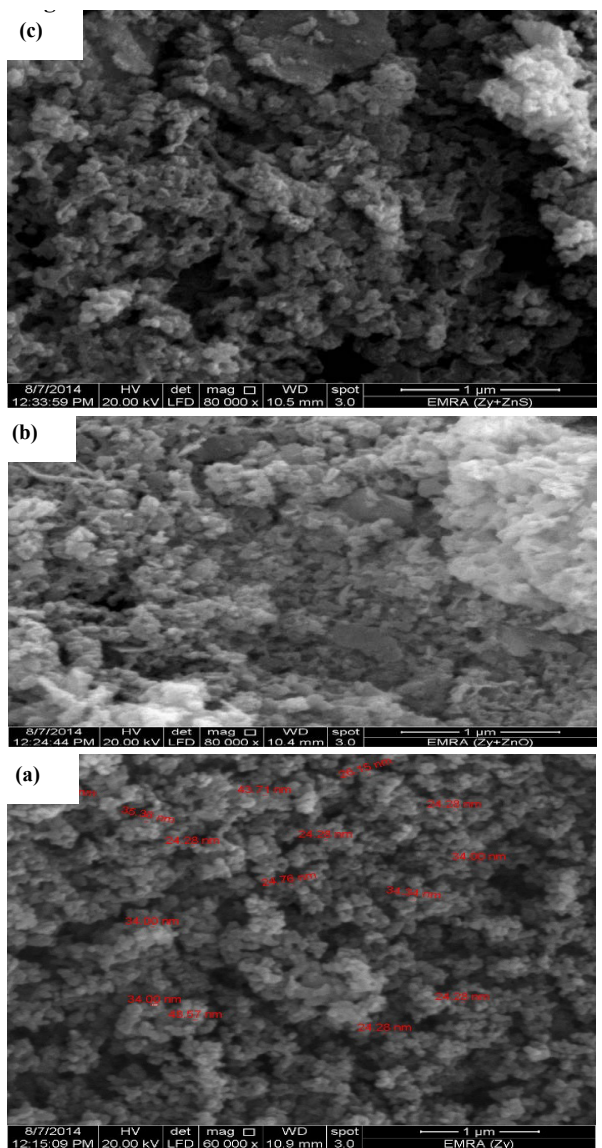

Figure 9: SEM images of (a) pure $\mathrm{NaY}$, (b) $\mathrm{ZnO} / \mathrm{NaY}$ and (c) $\mathrm{ZnS} / \mathrm{NaY}$ samples. 
(a)

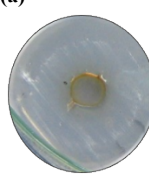

Streptococcus

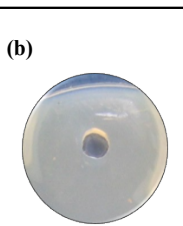

Streptococcus

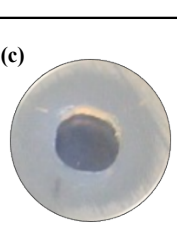

Streptococcus

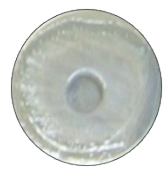

Bacillis subtilis

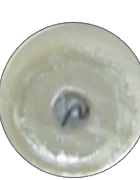

Bacillis subtilis

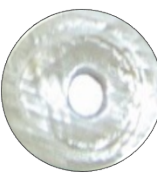

Bacillis subtilis

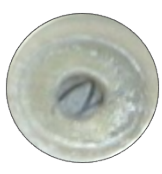

Escherichia coli

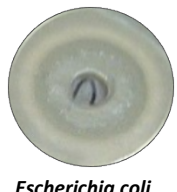

Escherichia coli

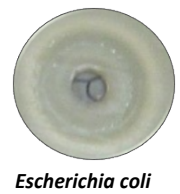

Figure 10: Antimicrobial activity for (a) pure $\mathrm{NaY}$; (b) $\mathrm{ZnO} / \mathrm{NaY}$ and (c) $\mathrm{ZnS} / \mathrm{NaY}$ for $B$. subtillus; Staphylococcus aureus and $E$. coli.

a randomly dispersed amorphous moiety within the pores. On the contrary, $\mathrm{ZnS}$ showed inhomogeneous aggregates most likely located in the supercage of $\mathrm{NaY}$ zeolite which gave rise to a new mesostructure. The $\mathrm{ZnS} / \mathrm{NaY}$ sample exhibited good bactericidal activity against selected bacterial species of gram negative and gram positive. Since this is easily available in the nation and also is used in hospital for biomedical agent, the active $\mathrm{ZnS} / \mathrm{NaY}$ can be prepared and used effectively for preventing the growth of the oral pathogens.

\section{References}

1. Szostak R (1997) Molecular Sieves. Blackie Academic \& Professional, New York, USA.

2. Ertl G, Knözinger H, Weitkamp J (1997) Handbook of Heterogeneous Catalysis, Wiley-VCH, Weinheim.

3. Hensen EJM, Van Veen JAR (2003) Encapsulation of transition metal sulfides in faujasite zeolite for hydroprocessing applications. Catal Today 86: 87-109.

4. Riley CR, Montgomery NE, Megally NN, Gunn JA, Davis LS (2012) Oxidation of cyclohexane by transition metal oxides on zeolites. The Open Catal J 5: 8-13.

5. Bhagiyalakshmi M, Yun LJ, Anuradha R, Jang HT (2010) Utilization of rice husk ash as silica source for the synthesis of mesoporous silicas and their application to $\mathrm{CO} 2$ adsorption through TREN/TEPA grafting. J Hazard Mater 175: 928-938.

6. Coutinho JS (2003) The combined benefits of CPF and RHA in improving the durability of concrete structures. Cem Concr Comp 25: 51-59.

7. Nair DG, Fraaij A, Klaassen AAK, Kentgens APM (2008) A structural investigation relating to the pozzolanic activity of rice husk ashes. Cem Conc Res 38: 861-869.

8. Katsuki H, Furuta S, Watari T, Komarneni S (2005) ZSM-5 zeolite/porous carbon composite: Conventional- and microwave-hydrothermal synthesis from carbonized rice husk. Micropor Mesopor Mat 86: 145-151.

9. Prasetyoko D, Ramli Z, Endud S, Hamdan H, Sulikowski B (2006) Conversion of rice husk ash to zeolite beta. Waste Manag 26: 1173-1179.

10. Sun L, Gong K (2001) Silicon-Based Materials from Rice Husks and Their Applications. Ind Eng Chem Res 40: 5861-5877.

11. Wang HP, Lin KS, Huang YJ, Li MC, Tsaur LK (1998) Synthesis of zeolite ZSM48 from rice husk ash. J Hazard Mater 58: 147-152.
12. Ali IO, Thabet MS, El-Nasser KS, Hassan AM, Salama TM (2012) Synthesis of nanosized ZSM-5 zeolite from rice straw using lignin as a template: Surfacemodified zeolite with quaternary ammonium cation for removal of chromium from aqueous solution. Micropor Mesopor Mater 160: 97-105.

13. Ali IO, Salama TM, Thabet MS, El-Nasser KS, Hassan AM (2013) Encapsulation of ferro- and ferricyanide complexes inside ZSM-5 zeolite synthesized from rice straw: Implications for synthesis of Prussian blue pigment. Mater Chem Phys 140: 81-88.

14. Ali IO, Hassan AM, Shaaban SM, Soliman KS (2011) Synthesis and characterization of ZSM-5 zeolite from rice husk ash and their adsorption of $\mathrm{Pb} 2+$ onto unmodified and surfactant-modified zeolite. Separ Purif Technol 83 38-44.

15. Grisdanurak N, Chiarakorn S, Wittayakun J (2003) Utilization of mesoporous molecular sieve synthesized from natural source rice husk silica to chlorinated volatile organic compounds (CVOCS) adsorption. Korean J Chem Eng 20: 950 955.

16. Wittayakun J, Khemthong P, Prayoonpokarach S (2008) Synthesis and characterization of zeolite $Y$ from rice husk silica. Korean J Chem Eng 25: 861-864

17. Matsui M, Kiyozumi Y, Yamamoto T, Mizushina Y, Mizukami F, et al. (2001) Selective adsorption of biopolymers on zeolites. Chemistry 7: 1555-1560.

18. Sakaguchi K, Matsui M, Mizukami F (2005) Applications of zeolite inorganic composites in biotechnology: current state and perspectives. Appl Microbiol Biotechnol 67: 306-311.

19. Chiku H, Matsui M, Murakami S, Kiyozumi Y, Mizukami F, et al. (2003) Zeolites as new chromatographic carriers for proteins--easy recovery of proteins adsorbed on zeolites by polyethylene glycol. Anal Biochem 318: 80-85.

20. Chiku H, Kawai A, Ishibashi T, Takehara M, Yanai T, et al. (2006) A novel protein refolding method using a zeolite. Anal Biochem 348: 307-314.

21. Kubota M, Nakabayashi T, Matsumoto $Y$, Shiomi T, Yamada $Y$, et al (2008) Selective adsorption of bacterial cells onto zeolites. Colloids Surf B Biointerfaces 64: 88-97.

22. Fereshteh Z, Loghman-Estarki MR, Razavi RS, Taheran M (2013) Template synthesis of zinc oxide nanoparticles entrapped in the zeolite $Y$ matrix and applying them for thermal control paint. Mater Sci Semi Proc 16: 547-553.

23. Sanatgar-Delshade E, Habibi-Yangjeh A, Khodadadi-Moghaddam M (2011) Hydrothermal low-temperature preparation and characterization of $\mathrm{ZnO}$ nanoparticles supported on natural zeolite as a highly efficient photocatalyst. Monatsh Chem 142: 119-129.

24. Hrenovic J, Milenkovic J, Daneu N, Kepcija RM, Rajic N (2012) Antimicrobial activity of metal oxide nanoparticles supported onto natural clinoptilolite. Chemosphere 88: 1103-1107.

25. Khatamian M, Divband B, Jodaei A (2012) Degradation of 4-nitrophenol (4-NP) using $\mathrm{ZnO}$ nanoparticles supported on zeolites and modeling of experimental results by artificial neural networks. Mater Chem Phys 134: 31-37.

26. Holder IA, Boyce ST (1994) Agar well diffusion assay testing of bacteria susceptibility to various antimicrobials in concentrations non-toxic for human cells in culture. Burns 20: 426-429.

27. Bragg WH, Bragg WL (1913) The structure of the diamond. Nature 91: 557.

28. Yu J, Cejka J, van Bekkum H, Cormma A, Ferdi SS (2007) Chapter 3 synthesis of zeolites. In: Studies in Surface Science and Catalysis. Elsevier, Amsterdam 39.

29. Zhdanov SP (1971) Molecular Sieve Zeolites-I. Adv Chem Ser 101: 20-43.

30. Wolfgang L (2014) Zeolite Y: Synthesis, Modification, and Properties-A Case Revisited. Adv Mater Sci Eng 2014: 724248.

31. Celik FE, Tae-Jin K, Bell AT (2010) Effect of zeolite framework type and Si/A ratio on dimethoxymethane carbonylation. J Catal 270: 185-195.

32. Quayle WH, Peeters G, De Roy GL, Vansant EF, Lunsford JH (1982) Synthesis and spectroscopic properties of divalent and trivalent tris(2,2'-dipyridine)iron complexes in zeolite Y. Inorg Chem 21: 2226-2231.

33. Salama TM, Othman I, Sirag M, El-Shobaky GA (2006) Comparative study of molybdenum oxide in $\mathrm{NaY}$ zeolite prepared by conventional impregnation and vapor-phase deposition techniques. Micropor Mesopor Mater 95: 312-320.

34. Flanigen EM, Khatami H, Szymenski HA (1971) Molecular Sieve Zeolites I. Advances in Chemistry Series 101. 
Citation: Salama TM, Ali IO, Gumaa HA, Lateef MA, Bakr MF (2016) Novel Synthesis of Nay Zeolite from Rice Husk Silica: Modification with Zno and Zns for Antibacterial Application. Chem Sci J 7: 118. doi:10.4172/2150-3494.1000118

Page 9 of 9

35. Flanigen EM (1976) Structural analysis by infrared spectroscopy, in Zeolite Chemistry and Catalysis. ACS Monograph, p: 171.

36. Sulikowski B (1996) Isomorphous replacement in the zeolitic frameworks: recent advances and implications. Heterogen Chem Rev 3: 203-268.

37. van Santen RA, Vogel DL (1989) Theoretical Heterogeneous Catalysis. Adv Solid State Chem 1: 151.

38. Sundaramurthy V, Lingappen N (2000) Isomorphic substitution of boron in ZSM-5 type zeolites using TBP as template. J Mol Catal A 160: 367-375.

39. Kazuo N (1972) Infrared and Raman spectra of inorganic and co-ordination compounds Part A: Theory and Applications in Inorganic Chemistry. 6th edn.

40. Penzien J, Haebner C, Jentys A, Köhler K, Müller TE, et al. (2004) Heterogeneous catalysts for hydroamination reactions: structure-activity relationship. J Catal 221: 302-312.

41. Thangam YY, Anitha R, Kavitha B (2012) Novel method to synthesize and characterize Zinc Sulfide nanoparticles. Int J Appl Sci Eng Res 1: 282-286.

42. Karge HG (1998) Characterization by infrared spectroscopy. Micropor Mesopor Mater 22: 547-549.

43. Khabtou S, Chevreau T, Lavalley JC (1994) Quantitative infrared study of the distinct acidic hydroxyl groups contained in modified $Y$ zeolites. Micro Mater 3: 133-148.
44. Ramos-Fernandez EV, Ferreira AFP, Sepulveda-Escribano A, Kapteijn F, Rodriguez-Reinoso F (2008) Enhancing the catalytic performance of $\mathrm{Pt} / \mathrm{ZnO}$ in the selective hydrogenation of cinnamaldehyde by $\mathrm{Cr}$ addition to the support. J Catal 258: 52-60.

45. Ramgir NS, Late DJ, Bhise AB, More MA, Mulla IS, et al. (2006) ZnO multipods, submicron wires, and spherical structures and their unique field emission behavior. J Phys Chem B 110: 18236-18242.

46. Gao S, Zhang H, Wang X, Deng R, Sun D, et al. (2006) ZnO-based hollow microspheres: biopolymer-assisted assemblies from $\mathrm{ZnO}$ nanorods. J Phys Chem B 110: 15847-15852.

47. Deng Z, Chen M, Gu G, Wu L (2008) A facile method to fabricate ZnO hollow spheres and their photocatalytic property. J Phys Chem B 112: 16-22.

48. Chastain J, King Jr RC (1995) Handbook of X-ray Photoelectron Spectroscopy. Physical Electronics, Inc., Eden Prairie, USA.

49. Vanaja M, Gnanajobitha G, Paulkumar K, Rajeshkumar S, Malarkodi C, et al. (2013) Phytosynthesis of silver nanoparticles by Cissus quadrangularis: influence of physicochemical factors. J Nanostructure Chem 3: 3-17.

50. Rajeshkumar S, Kannan C, Annadurai G (2012) Green synthesis of silver nanoparticles using marine brown Algae turbinaria conoides and its antibacterial activity. Intern J Pharma and Bio Sci 3: 502. 